\title{
ELECTRONIC COMMERCE: A BATTLE ON REGULATION, STANDARDS, TRANSPORTATION MEDIA AND BUSINESS INTEGRATION
}

\author{
Kim Viborg Andersen, Associate Professor \\ Niels Bjørn-Andersen, Professor \\ Niels Christian Juul, Associate Professor \\ Center for Electronic Commerce (CEC) \\ Department of Informatics, Copenhagen Business School \\ Howitzvej 60 \\ DK - 2000 Frederiksberg (DENMARK) \\ Phone: +45-3815-2400 \\ Fax: $+45-3815-240$ \\ E-mail kva.inf, nba.inf, ncjuul.inf//@cbs.dk \\ URL http://www.inf.cbs.dk \\ Please forward all comespondence regarding this submission to \\ Associate Professor, P.D. Kim Viborg Andersen at e-mail address andersen@ cbs.dk
}

\begin{abstract}
The drive towards the electronic commerce organisation is both a troublesome and a strifted path for government, enterprises and consumers worldwide. In this article we analyse the evolution of electronic commerce in Denmark during the period 1995-1998 from four perspectives: regulation, standards, transportation media and business integration.

The Danish government is stimulating the use of electronic commerce using direct and indirect policy initiatives on central, governmental regulation and establishment of greens enabling self-regulation. Also, the governments own, organisational management is in Denmark seen as a mean to exalt electronic commerce.

Onwards, the fist on proprietory standards and the UN/EDIFACT is an ongoing source of delaying, stimulating or preventing electronic commerce depending on the business sector and the size of market actor addressed. In Denmark, the direct access and value added network supporters have so far been the dominating mean to transport the electronic documents in the business transaction. The Intemet and XML technology is at the turn of the century challenging the way of doing business within this field. Some view this as the big blue to speed the diffusion of electronic commerce; others are worried that the incentive to investment and pull the partners in the value chain to use EDI might be lost. Finally, our study conclude that the debate on business integration issues is ambiguous and characterised by substantial uncertainty on for example the role of intermediates, direct sale, hyper-shift in business partners and the pull/push of global enterprises at the local markets.
\end{abstract}

\section{INTRODUCTION}

Major software houses like Oracle and IBM are setting up separate electronic commerce units. The major IS conference as the Pacific Asia Conference on Information Systems (PACIS), European Conference on Information Systems (ECIS), American Conference on Information Systems (ACIS) and the ICIS all are running tracks on electronic commerce. In addition, a variety of specially designated conferences (e.g., Bled International Conference on Electronic Commerce), workshop and job fairs are popping up on electronic commerce.

It is not all just talk and conferences. Approximately 50 per cent of Danish enterprises with more than five employees have access to the Internet. Almost 80 per cent of the enterprises communicate electronically via call connections or leased lines. Within the public sector, about 50 percent of the counties used the Internet to access information about products and services: $42 \%$ of the counties used the Internet to perform payment. In the municipalities, only about 5\% used it for payment purposes (Danish Ministry of Research and Information Technology, 1998).

Looking at the emerging bulk of electronic commerce literature there is major room for clarification on what is analysed: we need to address the how and why questions surrounding the ongoing development of electronic commerce path. In this article we point to the need for awareness of the business-to-business (B2B) electronic commerce in particular on standards, the transportation media and the business integration issues, we are not yet at the stage where our research models enable us to move onwards. Relying on an analysis of the B2B electronic commerce in Denmark, this article provides insight in the nature of each of these areas and suggestions for important research to be taken in the coming years entering the new millennium.

First of all, we outline our research model and the collection of data. Next, we address the ways the government in Denmark is stimulating the use of electronic commerce using direct and indirect policy initiatives on central, governmental regulation and establishment of greens enabling self-regulation. Also, the governments own, organisational management is in Denmark seen as a mean to exalt electronic commerce. We point to similarities both with respect to means and motives to the ones operating the business associations. We then provide B2B examples which use electronic commerce in Denmark.

An examination is then provided on proprietary standards and the UN/EDIFACT is an ongoing source of delaying, stimulating or preventing electronic commerce depending on the business sector and the size of market actor addressed. Also, we look at the transportation media. In Denmark, the direct access and value added network supporters have so far been the dominating mean to transport the electronic documents in the business 
transaction. The Internet and XML technology is at the turn of the century challenging the way of doing business within this field. Some view this as the big blue to speed the diffusion of electronic commerce; others are worried that the incentive to investment and pull the partners in the value chain to use EDI might be lost. Finally, we look at the contention on business integration issues is ambiguous and characterised by substantial uncertainty on for example the role of intermediates, direct sale, hyper-shift in business partners and the pull/push of global enterprises at the local markets.

\section{OUR RESEARCH MODEL AND COLLECTION OF DATA}

We view electronic commerce as a tripod of actors, work processes and products each being either physical by nature or digitised. In turn, we have eight cells of which seven qualify for our concept of electronic commerce. Our definition of electronic commerce is in line with the one proposed by Choi, Stahl and Whinton (1997) although we find the bulk of electronic commerce both at present and in the coming years to be driven by the business-to-business commerce rather than the business-to-consumer commerce. Also, we do view the public sector as a major market player in both the initiators and actual electronic commerce action. This active role is attributed to the large size of government in the Scandinavia countries and to the ongoing trend with publicprivate sector partnerships.

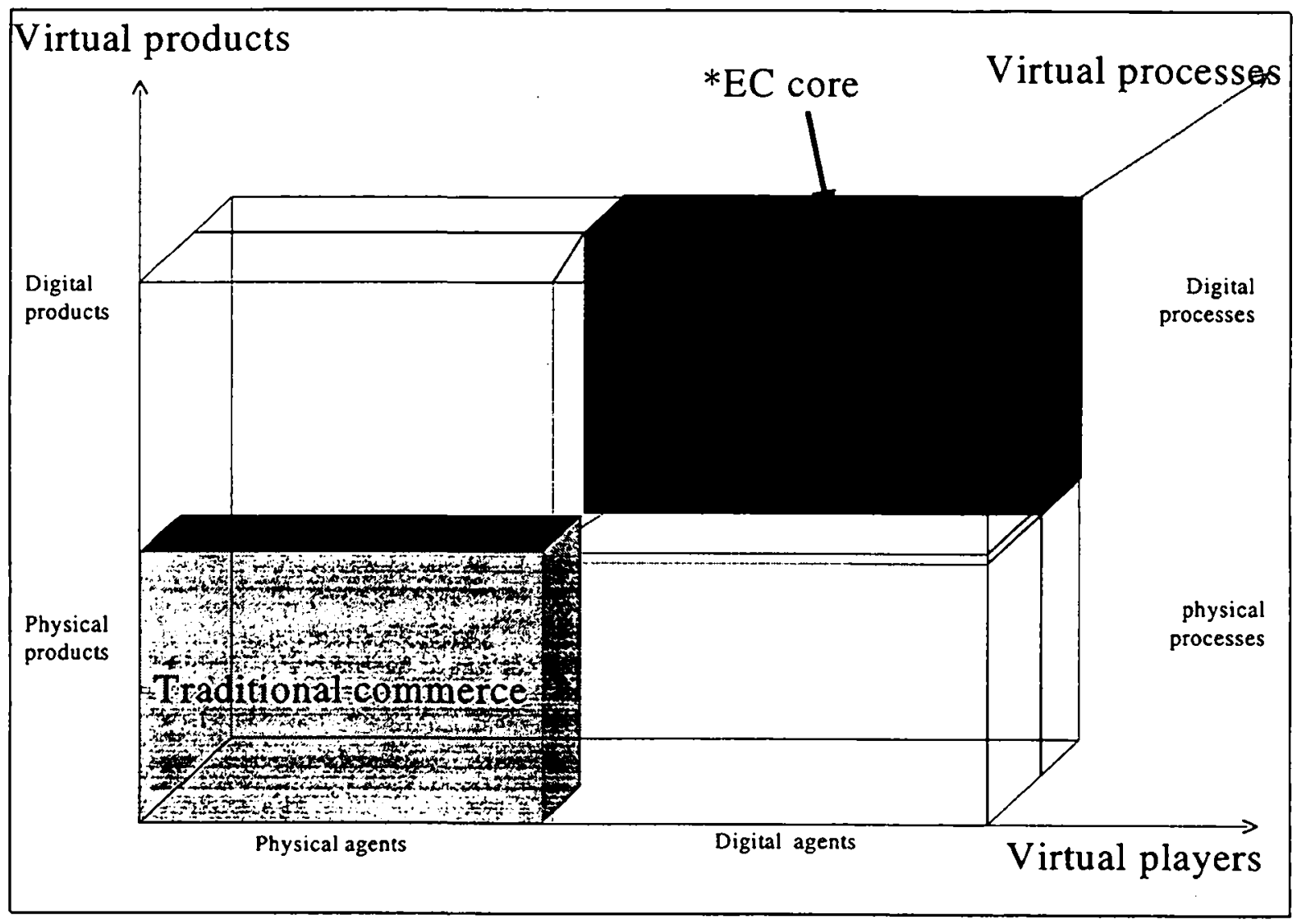

Figure 1.The electronic commerce tripod

Source. Modified after Choi, Stahl and Whinton (1997)

To obtain data on the business-to-business electronic commerce, data on number of messages and size of messages distributed on business sectors were obtained from the seven major VANS operators in Denmark. The data covered the period January 1 till June 30 1998. Also, we interviewed 14 business associations, eight major enterprises and eight public sector units directly involved in EDI-business (procurement, document exchange with the private sector on legal basis, or document exchange with international organisations within trade and statistics) (Andersen, Bjørn-Andersen, \& Juul, 1998). To obtain data on the business-to-consumer electronic commerce, we interviewed a total of 30 enterprises as well as analysing recent statistical surveys conducted by the Danish Ministry of Research and Information Technology, Statistics Denmark, OECD and IDC. 


\section{REGULATION: THE OLD FIGHT BETWEEN MARKETS AND GOVERNMENTS}

The EDI-strategy is by and large a consensus strategy among the corporate sector and the government. In Denmark the EDI Council is the administrative unit responsible for the electronic commerce strategy. The Ministry of Research and Information Technology and the Ministry of Business and Industry grant about DKK $18 \mathrm{~m}$ over a 3-year period to finance the increased activities of the Danish EDI Council. Moreover, these ministries provide a pool of DKK $6.6 \mathrm{~m}$ over a 3-year period to subsidise standardisation work, in particular, across industrial boundaries. These subsidies are distributed under the auspices of the Danish Agency for Development of Trade and Industry, as recommended by the Danish EDI Council. The national electronic commerce strategy formulated in 1996 has seven key areas:

\section{Establishment of EDI standards in all sectors}

2. EDI to be used for public procurement contracts under EU tendering by 1998

3. All public-sector financial systems should handle all commercial documents in EDI by the end of 1998

4. EDIFACT-based interchange of administrative information with the public sector in fax, statistics etc.

5. Development of EDI software to facilitate the above

6. Legislation on digital signatures and electronic documents by early 1998

7. Danish EDI Council to act as initiator and coordinator

The Headquarter Chief of Defense Denmark, the Danish State Railways, the Copenhagen Hospital Cooperation, the Danish Palaces and Properties Agency, as well as the Municipality of Copenhagen formulated an EDIstrategy to include their suppliers' ability to partake in EDI as an integral condition for inviting tenders as of 1998. Finally, the Danish government has made it official policy that all public procurement in year 2000 should be done using EDI.

It is our view that too much of the regulation debate concerns actions solely by governments ignoring the self regulation patterns in most business area where some governmental but more business associations corporate at national and international level to regulate their activity. Although government and business do hold conflicting motives, we find similarities in the means applied and the problems encountered for the institutional actions by business associations and government.

Governments and the actions taken to drive society towards the digital economy is in the long run at the mercy of the voters. Similarly the managers/ consultants of programs on electronic commerce within the business associations can be portrayed as balancing at the mercy of their members. Although we do not subscribe to this rational and non-conflictual view on decision-making in organisations, we do acknowledge these motives.

Indeed, business associations do hold their own motives that might in the short term differ from the preferences of the members. Encountering the actions taken by business associations one also find the endless line of seminars and information campaigns, videos, go-home-meetings, demonstration cases and financial support for development of prototype software.

To comprehend the structural features, the initiatives at the local level of government, and the operation management choices within the government, we propose to distinguish between whether the actions by institutions are direct or indirect in scope.

Direct actions are targeting EDI usage by subsidising the direct investment for ongoing EDI use, for example, by defining protocols for EDI use by customs and port authorities. Indirect actions capture initiatives which aim at increasing EDI "awareness" or acceptance, accomplished through public procurement as well as participation in EDI councils, international committees and special interest groups. We view both direct and indirect actions as having four modes:
1) pedagogical,
2) economic,
3) normative initiatives for the use of EDI in general, and
4) organisational management for the public sectors' own organisations.

These four categories encompass the categories outlined by Damsgaard and Lyytinen (1997) on "macro level factors that can affect EDI diffusion and how these factors are being modified through government intervention." We encompass both national governmental intervention modes, other overall macro-level factors (cultural, economic), supra national actions, and local governmental actions.

Thus, our four modes of action cover all these levels. Pedagogical initiatives involve knowledge dissemination with EDI seminars, materials aiming for improving EDI knowledge, and support for general EDI related research at the universities and international research committees.

Economic initiatives involve the provision of favourable, often subsidised, pricing for network services, as well as direct subsidies of EDI activities, either as "pilot-projects" or on a more permanent basis. 
Our third mode, normative initiatives, captures directives and legislation on syntax rules, data dictionaries, and document standards utilised in business transactions with the public sector. Finally, our forth mode, organisational management, focuses on the work processes in the public sector's own organisations and level of government. Due to a broader range of special interests, the politics of EDI management can be significantly more complex in the public sector. For example, the TEDIS project noted that in the public administrations' use of EDI,

"...Links between public administration and commercial organisations, for example, taxation, state insurance and statutory company declarations, form a significant special case. On the one hand the government departments responsible represent a monopoly, so at the local level they do not have to co-ordinate the introduction of electronic trading with any other equivalent body. However, public administrations lack the commercial pressures to seek efficiency improvements through IT innovations faced in the private sector. Also political considerations inhibit public bodies from insisting on trading by EDI, so they face the prospect of operating parallel systems for the foreseeable future (Graham \& Lobet-Maris, 1994).

Table 1. Classification of govermment actions in the electronic commerce area

\begin{tabular}{|c|c|c|}
\hline $\begin{array}{l}\text { Mode of } \\
\text { Intervention }\end{array}$ & Direct actions & Indirect actions \\
\hline Pedagogical & $\begin{array}{l}\text { - Knowledge deployment } \\
\text { - Innovation directives } \\
\text { - Transfer of EC technology }\end{array}$ & $\begin{array}{ll}\text { - } & \text { Mobilisation } \\
\text { - } & \text { Knowledge building } \\
\text { - } & \text { EC-councils } \\
\text { - } & \begin{array}{l}\text { Co-ordination of global electronic } \\
\text { commerce }\end{array}\end{array}$ \\
\hline
\end{tabular}

Economic - Direct subsidy of EC projects

Normative

- Innovation directive

- Standard setting

- Legislation on signature and EC
- Subsidy for educational EC-projects and general IT learning

- Subsidy for information infrastructure (for global electronic commerce)

- Provision of favourable charging modes for network services

- Innovation directive

- Standard setting

electronic - Public procurement

- Adoption of private management techniques

management

- Legislation on the use of electronic signature and EC

- Services reengineered to be more consumer oriented

- Co-ordination of electronic commerce with governments abroad
- Collaborative working relationship

- Balance of power in government 
In Table 1 the first three modes encompass the traditional government actions. But organisational management is equally important to each of these three modes, since, in many countries, such as Denmark, the public sector may be a more avid user of EDI than the private sector. Consequently, government actions may affect both the demand-pull as well as the supply-push for EDI in the private sector. Accordingly, when we address the question "how does government intervention affect the EDI-diffusion process", both the public sector's diffusion and the private sector's adaptation are of equal interest.

In addition, the plethora of instruments outlined in Table 1 reflects how complicated it is to stimulate the diffusion of electronic commerce and to estimate how government intervention affects the process. For example, the TradeNet in Singapore did not achieve success status merely by bottom-line analysis and top-down steering. Instead, this example showed the need to stimulate and evaluate EDI diffusion in its organisational context, public or private regardless. Also, local government and quasi-governmental organisations might be just as successful, or more so, in initiating low-cost EDI solutions compared with central government.

We believe this is a very important observation given that governments have multiple forms and the distinction between private and public is no longer as clear as it was a century ago. Moreover, the spread of semi-public companies is changing the roles of politicians, managers and the staff in the public sector and influencing the mien of the private sector. In addressing EDI and data networking these changes in the environment, both the political and the commercial elements, pose challenges for the successful diffusion of EDI. All too often this notion is ignored (Saxena \& Wagenaar, 1997; Scala \& MacGrath, 1993).

Accordingly, governments might not see it as their primary role to pursue top-down steering or legislation of the EDI diffusion process. Using such crude strategy might stifle innovation, discourage competition, and eventually leave the national economy worse off. Instead, central government should move onward on a large variety of fronts including fostering conditions that tear down obstacles for effective EDI use. More specific examples could be encouraging legislation for digital signatures, investing and building an information technology infrastructure, as well as organising a watchdog against monopoly practices. Within the public and the private sector, we have found some very interesting B2B examples.

\section{EXAMPLES ON B2B ELECTRONIC COMMERCE}

\section{The Danish National Board of Industrial Injuries}

The Danish National Board of Industrial Injuries is a financially autonomous agency under the Ministry of Social Affairs handling individual work related injuries. The work process involves retrieval of data, checking of legal data/ reference materials, and co-working with other colleagues in the office. Most contact outside the organisation is done through traditional mail (incoming mail is scanned) and phone. Within the organisation communication is either face-to-face meetings, phone meetings, memos, and exchange of electronic documents. In 1995, the Board received 327,000 letters, while they sent off 375,000 letters. They received 46,000 notifications of injuries and made 90,000 decisions.

In 1997, the insurance companies and the Board started using EDI. The insurance companies are required by law to use the board in cases of worker compensation related to injuries. The Board needs to check insurance numbers, the insurance companies need to check social security numbers. By using EDI, the two partners have bypassed a legal barrier, which prohibits insurance companies from obtaining direct access to centrally stored personal data.

\section{Public procurement}

The most demanding challenge for the near future is to implement EDI based electronic trade into public purchasing. While the need to obtain cost reductions in administrative processes is evident, the barriers of technique, tradition and attitude are still pervasive.

National Procurement has assumed a major role in preparing the public sector in Denmark for the electronic purchase of the goods and services. In 1997, National Procurement Ltd. introduced an EDIFACT based database which encompassed all goods and services in the current paper based Purchasing System. In addition, an electronic public purchasing system has been designed in cooperation with the national and local public network operators.

These two systems are completed with EAN location numbers for all subscribers as well as a set of EDI documents and standards which will form the backbone of a thorough public trade environment. This will be combined with an open interface to other 3rd party goods and services databases and administrative systems used in the public sector

In the course of 1998 all public authorities will be able to commence transacting via EDI. Together with National Procurement, Ltd., the Agency for Financial management and Administrative Affairs is developing a basic procurement system for public economic management systems. The procurement system became operative for municipal and central government users as of February 151998. 


\section{Taxation}

The Danish Central Customs and Tax Administration (Customs*Tax) aims to receive all documents electronically. Their EDI strategy consists of two major elements: 1) A strategy for the handling of all incoming data from companies electronically through an alliance with the Statistics Denmark and the Danish Commerce and Companies Agency, Ministry of Business and Industry; 2) enabling citizens to deliver their advance tax assessments and income tax statements via the Internet and voice-response. The requirements for EDI applications used by Customs*'Tax customers are:

1. Right amount on time.

2. Better servicing of companies, including a reduced effort on their behalf.

3. Effective use of resources.

4. Correct and lawful administration.

5. Development oriented.

6. Political satisfaction.

The new EDI interface developed by Statistics Denmark, Danish Commerce and Companies Agency, the Ministry of Business and Industry, and the Central Customs and Tax Administration enables companies to deliver their declaration regarding VAT and individual article tax electronically. In 1997, more than $20 \%$ of all Danes made use of the service to enter and transmit information for the advance tax assessment and the income tax return by telephone. Less than $1 \%$ used the Internet for this task in 1997.

Table 2. Central Customs and Tax Administration: Documents handled manual and electronically, 1997 (1,000)

\begin{tabular}{|c|c|c|c|}
\hline \multirow[t]{2}{*}{ Document: } & \multirow{2}{*}{$\begin{array}{c}\text { Manual data } \\
\text { entry }\end{array}$} & \multicolumn{2}{|c|}{ Electronic data transfer } \\
\hline & & EDI & Phone \\
\hline Employers' income statement & 1,000 & 10,000 & 0 \\
\hline Interest (financial institutions) & 150 & 31,000 & 0 \\
\hline Trade union dues & 100 & 5,300 & 0 \\
\hline Income tax statement & 780 & $30^{2)}$ & 600 \\
\hline VAT & 1,600 & 0 & 0 \\
\hline Intrastat & 900 & 4,000 & 0 \\
\hline Import and export, total & 2,800 & 1,100 & 0 \\
\hline
\end{tabular}

a) Via Internet

Health sector

The Danish health care sector is considered to be one of the most automated in Europe. Currently, 15\% of discharge letters, $7 \%$ of laboratory results, and $10 \%$ of pharmacy prescriptions are handled by EDI on average. In the Copenhagen municipality, EDI is also used in the communication with the dentists and eye specialists.

Within Fuen county, the general practitioner (GP) sends a referral to the hospital department, and the hospital sends discharge letters to the GP and the municipal social administration and the health insurance using EDI (Andersen, 1998; Fuen County, 1995, 1996). Also, when the pharmacy, hospital and GP order medicine, EDI is replacing paper based order and invoice forms. Currently, the FuenCom project is being expanded to cover the entire country (MedCom).

After establishing a Computerized health data network within the organisation, the county estimated that substantial revenue had been achieved (Fuen County, 1996, p. 46). There is, however, major variance in how much of the communication is wired. In Figure 2, we compare the communication in Fuen and the average communication in Denmark based on the number of letters of discharge, prescriptions, pharmacies, laboratory test results, and doctor's practices.

Twenty-seven percent of the letters of discharge are Computerized and are part of a network in Fuen County. Yet, at the national level, only 10 percent of the letters of discharge are part of a network. Most remarkable, however, is that almost 80 percent of the laboratories send and receive their messages through electronic communication in Fuen County, whereas only 20 percent of the communication in the labs are processed electronically at the national level. Furthermore, more than 4 out of 5 pharmacies are wired. This is true for Fuen County as well as the national average. 
Figure 2 Example of EDI in the Danish health sector

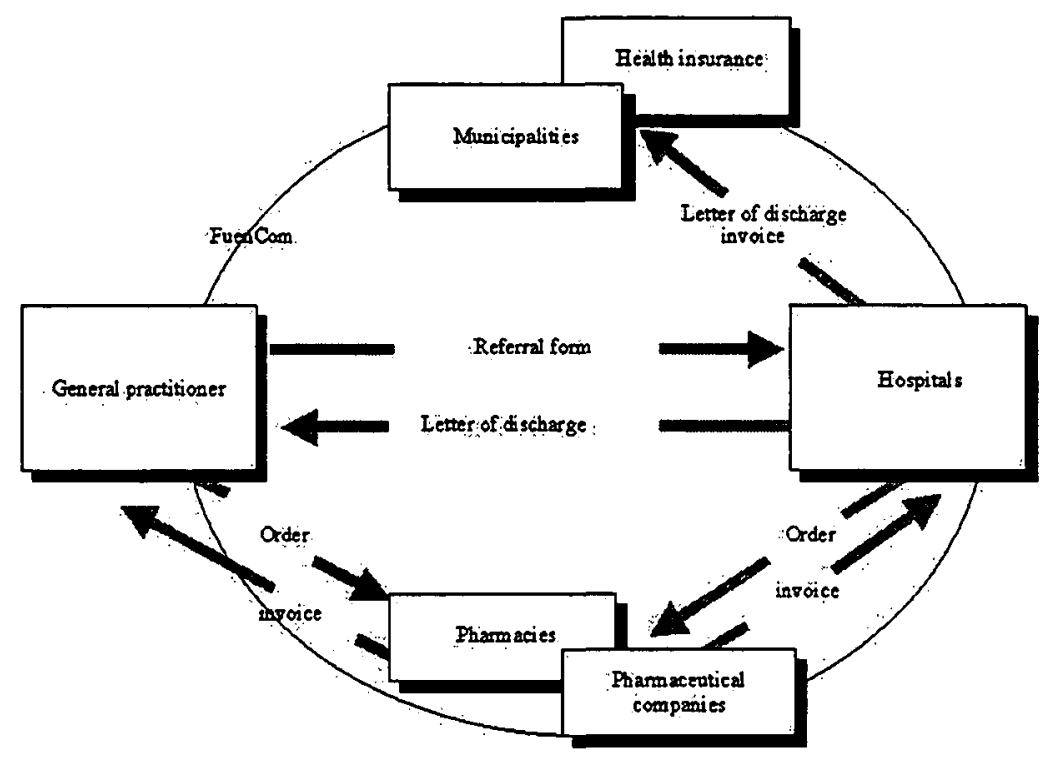

Source. Constructed after Fuen County (1995, 1996)

Source. Andersen, Ed. (1997), Andersen (1998)

The large companies apply EDI both internally between a company's departments at home and abroad and in relation to suppliers and the distribution link. There is hardly any application of EDI in relation to small buyers of products. Owing to the dissemination of Efficient Consumer Response (ECR), especially in the provisions trade, EDI application has increased as Electronic Point of Sales (EPOS) systems use the HANCOM standard. In January 1997, Dansk Supermarket started to use EDI invoices, and at present the company runs a production with 29 suppliers. From 1996 to 1997 the number of suppliers with EDI application has increased by 61 per cent. Measured in terms of order items the number has increased by 27 per cent in the same period.

Approx. 80 ' $\leq \mathrm{r}$ cent of the deliveries to FDB's stores are made via the central warehouses. All communication to the stores . ' vde via an internal computer system that does not apply EDI format. There are no plans to change the syster $\cdots$ is not applied in connection with domestic transports, however, it is extensively applied in connectio in transport abroad. Shipping via Dantransport enables FDB to get EDI information about e.g. cargo fro Is ine Far East. Together with DSB Gods the company also participates in a development project on EDI application in connection with full-load transport of goods.

FDB has been a pioneer in the application of EDI in Danish provisions trade, and they made the first EDI messages (orders and invoices) in 1991 after HANCOM was released the first time. Already in the 1970's, FDB made their own proprietary standards with meat packers, the dairy industry, breweries and newspaper headquarters. At present (1997), FDB receives 96 per cent of all invoices in EDI format. In 1995, the figure was 85 per cent. The remaining percentages are made up of small companies or suppliers that only perform a small amount of trade with FDB. From this category FDB may still receive hand written invoices. Placing orders is done via EDI, letter or fax, where roughly half the orders are placed via EDI. FDB has approx. 1,200 suppliers, and roughly 400 have agreed to apply EDI. The major part of the transfers are batch-transfers. Not only don't the smallest suppliers use EDI, but some of the large suppliers have been slow to implement the technology. According to FDB it is only a minority of suppliers that will take the lead. 
Figure 3. Network Distributed Messages in Fuen and in Denmark on Average

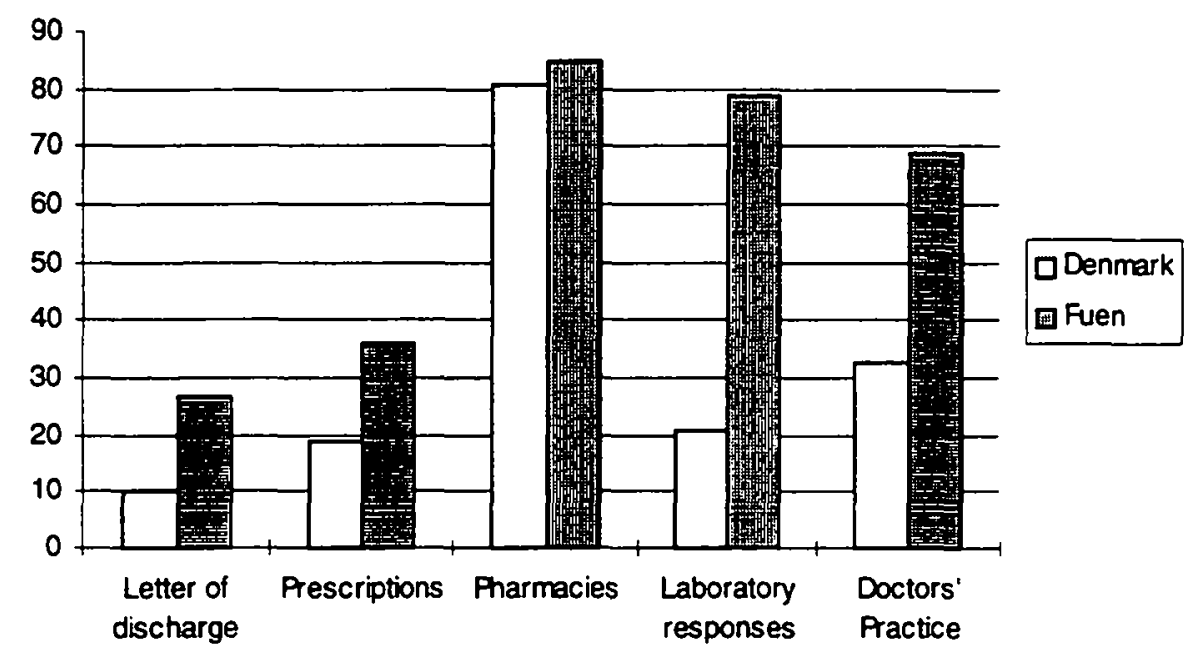

Note. Data provided by the Danish Center for Health Informatics

\section{The retail sector: Dansk Supermarket and FDB}

FDB's deliveries to local authorities are not part of the National Procurement Ltd. agreement. Local authorities' procurement to institutions comprises e.g. small, daily purchases of food, etc. At present, efforts are being made to introduce a card solution to FDB, where purchases automatically will be forwarded to the Basis Procurement system and thus reduce the high costs of processing and forwarding paper invoices. The project is carried out in cooperation with Kommunedata (computer center of local authorities).

FDB does not use the Internet in connection with orders and invoices. In 1996, FDB made an experiment with placing orders via the Internet in Vellev in Jutland, where the local FDB store had been closed down. FDB evaluates that the Internet may become a competitor to VANS.

\section{Toy manufacturing: LEGO}

According to LEGO, EDI application is only an advantage provided bar coding and tracking of goods have been introduced as well. Most of LEGO's activity within the EDI area is focused on sales. Partly, LEGO applies EDI at an advantage, and partly EDI is a necessary condition for implementing Efficient Consumer Response in the company.

In Denmark, orders and invoices are run in EDIFACT. There is no venture management in the Danish part of LEGO. A fairly small number of stores use Computerized cash registers in connection with reordering goods due to lack of precision in data registration. EDI application is considerably more popular in the American part of LEGO than in the European departments. It is not a problem that ANSI standards are used in the USA and EDIFACT in Europe as the two systems are not integrated.

As 60 per cent of the turnover is made in the Christmas month, the stock must be built up to reach its peak in September/October. LEGO applies the just-in-time principle in connection with all large business transactions. The principles from the provisions trade have spilled over into the toy business. EDI is not used in relation to toy chains, etc. They place their orders by fax or via a sales representative.

In a large number of areas EDI application in Europe is way behind EDI in the USA, where LEGO has almost 100 per cent of its customers on EDI. At the same time, LEGO has achieved a drastic increase in sales. Small distribution costs, just-in-time and efficient order and delivery control are some of the principal factors. Chains, such as Walmar, require that suppliers apply EDI. In the USA, the concept is larger chains, operated especially by companies such as Walmart on the EDI area. As a consequence, there is a great pressure on the retail area. In addition to the provisions trade, it applies to the branded goods area, especially Proctor \& Gamble. Previously, a chain, such as Walmart, fought with brand mark producers about discounts in connection with large orders. Now the trend is to secure advantages for both the company placing the order and the producer by manufacturing directly for delivery instead of for building up expensive stocks.

In the USA, the smallest sales unit is a carton, in Denmark it is a single package. It goes without saying that the logistic needs are many times bigger. Within the transport department area all booking, tracking, invoicing, including statistics are made via EDI. 


\section{Production plants: Grundfos and Danfoss}

Already before the EDI Agenda was introduced, Grundfos and Danfoss engaged in a complete application of EDIFACT. Grundfos has an extensive use of EDI in connection with suppliers, shipping and between the company's departments (17) in Denmark and abroad. Grundfos has been a front runner in relation to EDI application and had already in 1990 started on electronic document interchange, where a substantial part was in EDIFACT format. They apply EDIFACT in connection with orders, invoices and delivery status. 20 per cent of the communication with suppliers is via EDIFACT. All communication with shipping in Denmark is in EDIFACT format. Between the company departments $80-90$ per cent of communication on orders, invoices and delivery is via EDIFACT. These figures have not changed since 1995.

At present, Grundfos is implementing SAP-R3 in production and management accounting systems. This may imply a larger number of electronic documents in addition to a more extensive integration of subsidiaries. Naturally, it becomes a question whether it is possible to measure the EDIFACT application merely by the VANS traffic, as it will depend on the form of communication chosen for sending data between the different departments.

Danfoss applies EDI between the individual (financially separated) units. Primarily, Danfoss markets its products through the subsidiaries, which involves a range of business transactions where EDI can be used due to the great volume in communication. Orders and invoices are sent between all business units in Danfoss.

In the last 10-15 years, the company has engaged in EDI, i.e. before the industry associations and the government seriously began to focus on EDIFACT. Therefore, the group was forced to develop their own applications and document layout. In 1998, this is still apparent as roughly 70 per cent of all electronic communication is made via their own proprietary standards and only 30 per cent in EDIFACT format. However, it has not been possible to make an estimate of the marketing subsidiaries' EDI communication with their customers.

In the electronic post office in Danfoss (GATE) there is an interchange of data between the different product divisions (10-15), marketing subsidiaries (30-40) and production facilities (10-20) and with external relations (banks, suppliers, shipping agents, Central Customs and Tax Administration, etc.). They are spread all over the world. The communication goes via Infonet, Dan Net and IBM Global Network.

Danfoss has 15-20 trading partners with whom they have exchanged invoices, orders and order confirmations over the past 5-7 years. A new element is transport companies. On the Danish market Danfoss cooperates with a few large transport companies where EDIFACT is applied.

Another new element in Danfoss (since October 1997) is Web-business applications, where a customer can place an order in different parts of Danfoss via Internet. Up till now two applications have been developed. They handle placing of orders (customer side) and order confirmation (supplier side). Invoices, etc. cannot be sent. Orders placed via form-based EDI are converted in GATE to normal EDI format and forwarded to the production unit.

\section{Shipping: Marsk}

Operationally, Mærsk shipping line is covered 100 per cent by EDIFACT in terms of bayplan and the large ports such as Rotterdam and Felixstove. Roughly, Mærsk shipping line receives 1 million EDIFACT messages a month and sends 500,000. In terms of customer relations the company receives approx. 200 consignment notes and bookings daily via EDIFACT application. Settlement of payments is not run via EDIFACT. EDIFACT messages are received via VANS operators and as attached files to e-mail. The option to send orders by e-mail is especially employed by small companies.

\section{THE BATTLE OF STANDARDS}

Throughout the 1990s journals and conferences proceedings were filled with questions on whether EDI and in particular EDIFACT/ ANSI X.12 would tighten business partners so much that the market clearing mechanisms were threaten. Economists were speculating on whether the costs related to a potential decreased search for market alternatives would exceed the benefits achieved on reducing transaction costs and lowering the error ratio of re-keying the data in the value chain.

Turning to the VANS based traffic, our data show that there has been sent about 45 percent more messages annually and 33\% larger volume of messages (bytes). In particular, the health area, finance and distribution use VANS operators 
Table 3. EDIFACT traffic in Denmark, 1995-1997.

\begin{tabular}{|c|c|c|c|c|}
\hline \multirow[t]{2}{*}{ Year } & \multicolumn{2}{|c|}{ Bytes } & \multicolumn{2}{|c|}{ Messages } \\
\hline & $N$ & $\begin{array}{c}\text { Annual } \\
\text { growth (\%) }\end{array}$ & $\mathbf{N}$ & $\begin{array}{c}\text { Annual growth } \\
(\%)\end{array}$ \\
\hline 1997 & 57.110 .724 & & 26.593 .813 & \\
\hline & & $33 \%$ & & $45 \%$ \\
\hline 1996 & 43.007 .936 & $33 \%$ & 18.401 .306 & $46 \%$ \\
\hline 1995 & 32.375 .495 & & 12.630 .458 & \\
\hline
\end{tabular}

In Figure 4 and 5 we have analysed the VANS based traffic for all VANS operators in Denmark. The adjusted line (dotted) in Figure 1 where $y$ equals $47.996 x+712.793$, with $y$ representing the number of messages and $x$ is the time (months). R-square for the simple regression line is 0,96 . Also, the data can be analysed applying an exp function with y equal to $850.538 \mathrm{e}^{0.0313 x}$. the data show a rapid growth in the last part of the period included in our data material.

Figure 4. EDIFACT via VANS 1995-1997 (months and messages)

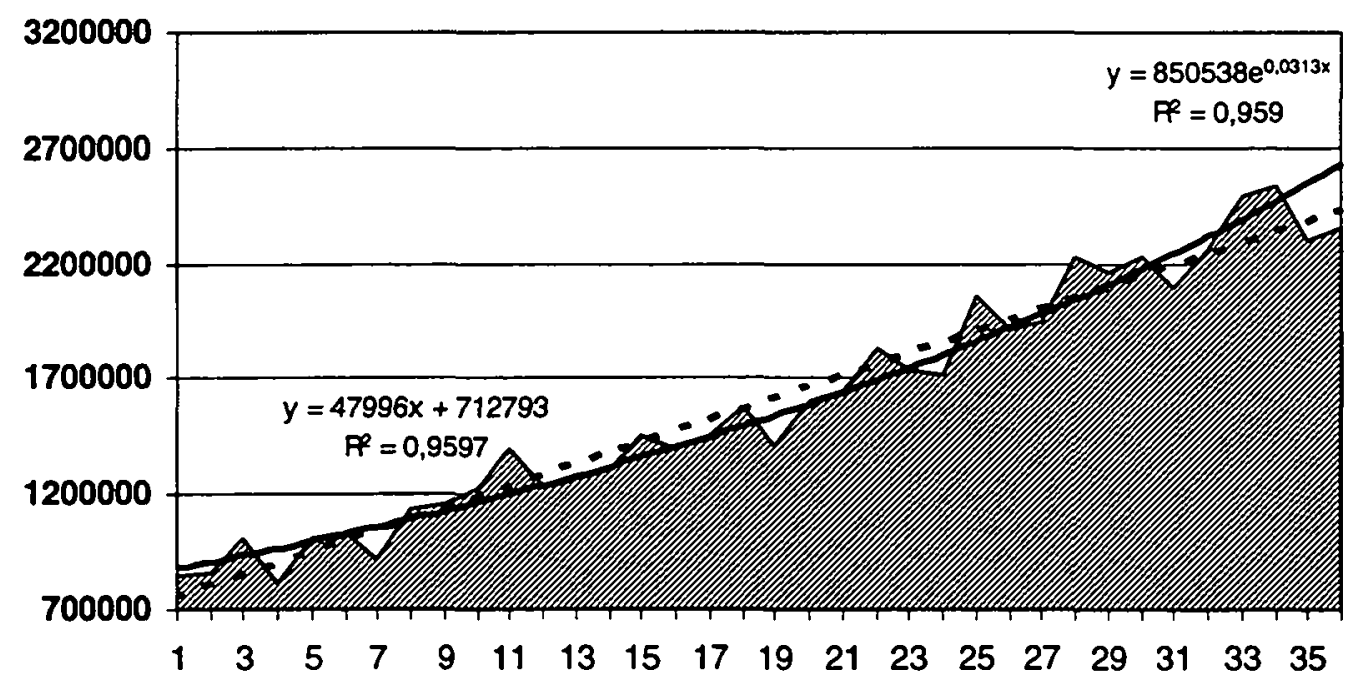

Similarly, in Figure 5 we have analysed the VANS traffic measured by bytes. The adjusted curve is y equals $84.572 x+2.200 .384$, with $r$-square $=0,9$. Applying an exponential-function provide, however, a better $r$-square on 0,91 . 
Figure 5. EDIFACT via VANS 1995-1997 (months and bytes)

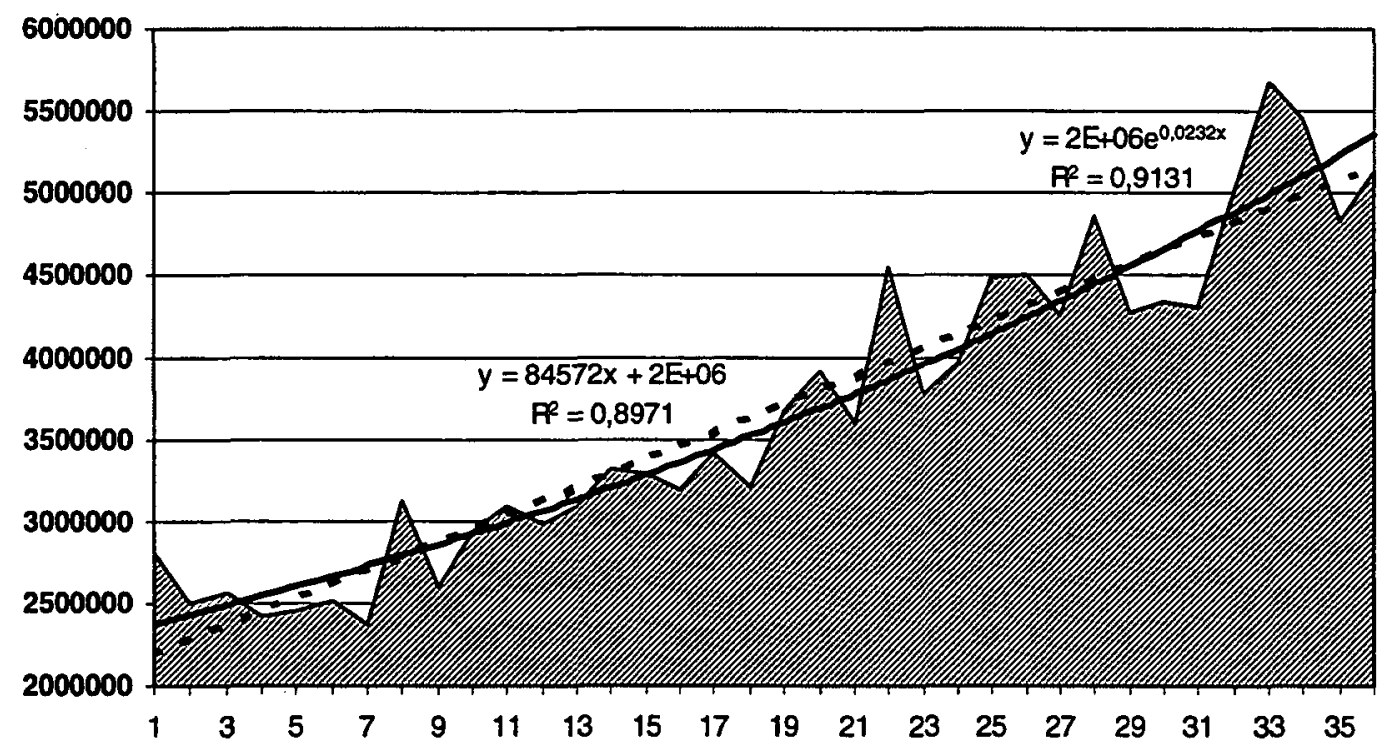

Rather than using VANS operators, one might use the INTERNET for EDI. Approximately 50 per cent of Danish enterprises with more than 5 employees have access to the Internet. Almost 80 per cent of the enterprises communicate electronically from the enterprise via call connections or leased lines. When considering the variety of tasks, in which EDI is used, approximately 50 percent of the counties used it to obtain information about products and services, whereas roughly 42 percent use it for payment. By contrast, only $5 \%$ of the municipalities used it for payment purposes. Thus counties appear to have a significant lead in utilising electronic commerce. This is most likely attributable to the business-to-business EDI predominance in the health sector, which are primarily administrated by the counties in Denmark.

\section{CARRIAGE MEDIA TRANSFORMATION}

Using Internet technology one has the potential to substitute the use of VANS operators or direct access in favour of Internet EDI solutions, labelled browser-EDI in this article. This triangle of transportation media might not be an either or, rather it is often complementary modes of transportation such that some require and use direct access, others, VANS-based communication while others settle the Internet mediated EDI solution.

As we have seen in the previous section, the VANS operators were not out of business or showing any indication of less market growth. However, in the coming years there might be an expansion in the EDI market using other techniques for transportation. Rather than using VANS operators, one might use the Internet for EDI carriage. Approximately 50 per cent of Danish enterprises with more than 5 employees have access to the Internet. Almost 80 per cent of the enterprises communicate electronically from the enterprise via call connections or leased lines. Interviewing business organisations and key informants in the public sector, we found that overall they estimate an immense potential for the EDI usage within the next two years. Nine out of ten indicated that $90 \%$ of the current paper documents can be transformed to electronic forms transported either through the Internet, direct access or VANS-operators. The data is shown in the first column in Table 4. We also asked the respondents to give their estimate on where the potential for transforming paper based documents to electronic forms is most likely to be completed using VANS, Internet or direct access line. The opinions on these future trends are shown in columns two, three and four, each distributed on business sector. 
Figure 6. The transportation media, integration, format triangle

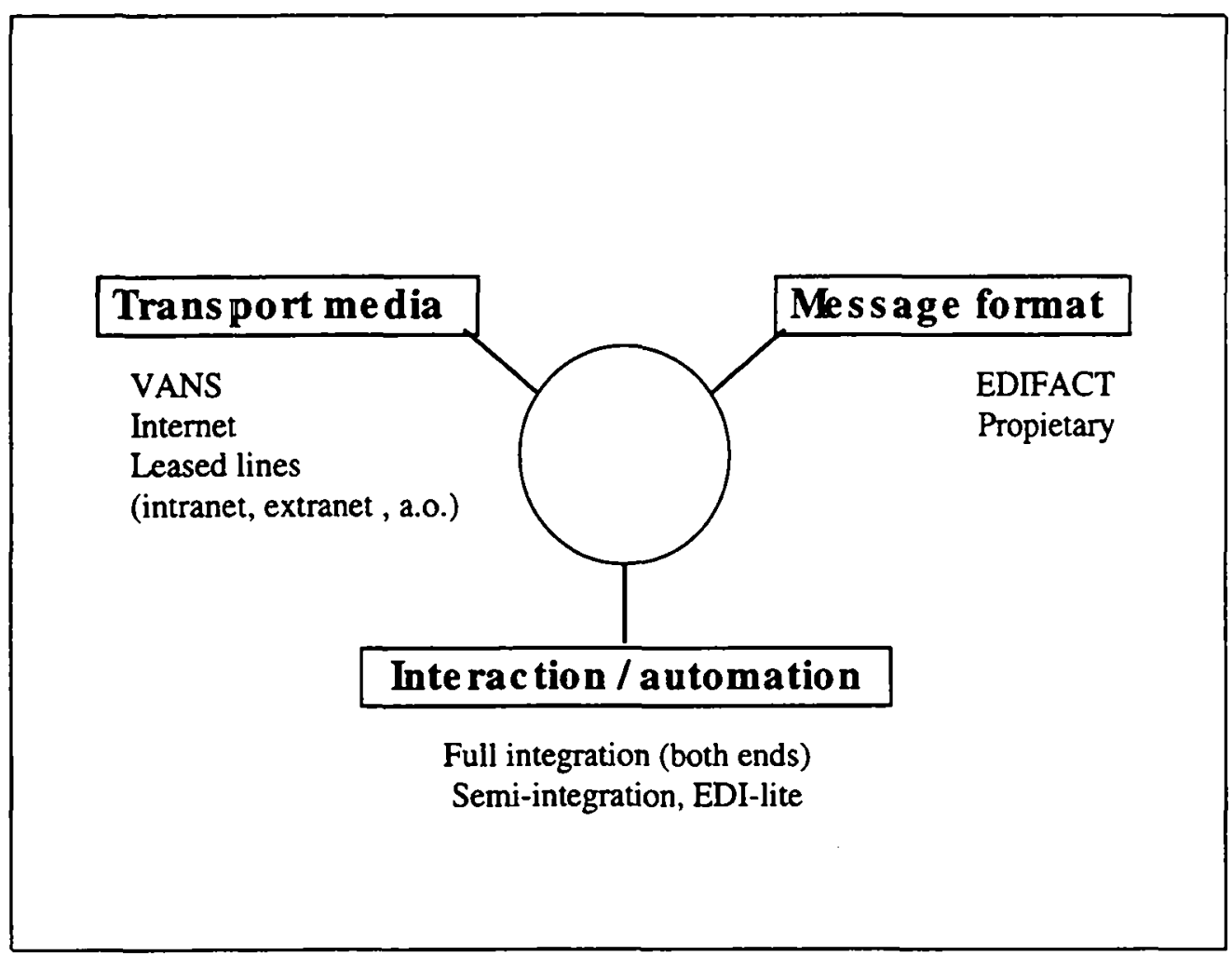

Table 4. EDI transportation media

\begin{tabular}{|l|l|c|c|c|c|}
\hline Business sector & $\begin{array}{c}\text { Potential } \\
\text { for using } \\
\text { EDI }\end{array}$ & \multicolumn{3}{l|}{ Transportation mode/ standard } \\
\hline & & \multicolumn{2}{|c|}{$\begin{array}{c}\text { Proprieto } \\
\text { ry }\end{array}$} & EDIFACT & $\begin{array}{c}\text { Browser- } \\
\text { EDI }\end{array}$ \\
\hline & National & \multicolumn{4}{|c|}{- percent --- } \\
\hline $\begin{array}{l}\text { The public } \\
\text { sector }\end{array}$ & 50 & 10 & 15 & 15 \\
\hline & Counties & 60 & 10 & 20 & 10 \\
\hline & Local government & $50-60$ & 10 & 25 & 1 \\
\hline $\begin{array}{l}\text { Insurance } \\
\text { companies } \\
\text { and banks }\end{array}$ & Insurance and pension & $30-40$ & 10 & 50 & 1 \\
\hline & & & & & \\
\hline & Banks & $20-30$ & 75 & 2 & 0.1 \\
\hline $\begin{array}{l}\text { Industry and } \\
\text { commerce }\end{array}$ & Real estate & $20-30$ & 75 & n.a & 1 \\
\hline & Industry & $80-85$ & n.a & 15 & 1 \\
\hline & Wholesale & 95 & n.a & 5 & 1 \\
\hline & Carpenters etc. (SMEs) & 95 & n.a & 5 & 1 \\
\hline & Construction & 95 & n.a & 5 & 1 \\
\hline & Consumer commerce & $70-80$ & n.a & 25 & 1 \\
\hline & Agriculture & $30-40$ & n.a & 30 & 10 \\
\hline $\begin{array}{l}\text { Transportatio } \\
\text { n }\end{array}$ & Heavy freight & 30 & 30 & 30 & 10 \\
\hline & Letters and packaging & 40 & 20 & 25 & 10 \\
\hline & Shipping & $20-30$ & 30 & 30 & 15 \\
\hline
\end{tabular}


The EDI technology might be fully integrated or semi-integrated and as such can is used to reach not only SMEs but also end-consumers. The spread of XML-technology can spiral this. In our interviews with business leaders in business associations, enterprises and public sector institutions most indicated a major shift in the use of transportation media for EDI. The winner might be the stakeholder in the Internet.

\section{THE DREAM WAVE KEEPS COMING}

Business consultants worldwide sell the dreams of the ultimate integration of dataflow within the department and with the business partners. Enterprise systems such as SAP and Oracle are the latest elements in the drive towards the fully integrated organisation. Yet, the nightmare of multiple data-reentry, scanning invoices, mailing letters in hard cover form, ordering computer manual by fax continues. Most organisations today run multiple formats of data, among them the digital format appears in yet more instances.

The Danish government made it a policy goal that by year 2000 all public procurement should be done electronically. At the time (1996) of the policy formulation, this implied the use of EDI-systems through other channels than the Internet as this was not advanced to a stage where issues as technology, security and trust were advanced to an implementation stage. The Internet technologies were at that time in the making. The policy commitment to EDI-use spiralled a policy debate quite similar to the one on Internet use: would it benefit the larger, international owned countries, would the local shops loose business, would the local community suffer as a result of the business transformation?

This classical dilemma faced in the municipality of Skive, the design of new EDI system labelled "Basisshopping" developed by the partners (Local Government Computing Association, the Økonomistyrelsen and the Statens and Kommunernes Indkøbsservice) in the VIBE-project.

In Skive municipalities there are about 1,000 suppliers ranging from the bakery with fresh bread supply to the kindergarten, to the computer suppliers, to the accounting department and the car supplier, to the road construction department.

The accounting department handling all the bills and accounting processing data, signed up with suppliers to use EDI systems to decrease the costs of keying the incoming bills, transferring the payment and in processing the data on to the accounting and financial systems. Along with the installation of the EDI-converters and the offer to the business-partners to join in, a scanner was installed in the accounting department.

By year 1 after the EDI-systems was in use, only 18 of the suppliers signed up for the EDIFACT-system. However, the accounting benefited immensely from the investment in a scanner enabling electronic bookkeeping. When we look at the data for Danish local government in general for 1997 , only $8 \%$ of the municipalities used EDI, whereas $75 \%$ of the counties and $15 \%$ of the private enterprises used electronic commerce in the procurement function. Thus while EDI adoption has been quite successful at the county level, substantial opportunities exist for increasing electronic transacting at the lower governmental levels.

60 per cent of the ministries and 36 per cent of agencies and directorates have a home page. 90 per cent of the ministries and 53 per cent of agencies and directorates may be contacted via an official E-mail address. 36 per cent of the counties have a home page and 64 per cent have an E-mail address. 16 per cent of the municipalities have a home page and 30 per cent have an E-mail address (Danish Ministry of Research and Information Technology, 1997).

Accessing the overall use of IT to reconfigure organisations, most of the applications are localised or internal integration. However, there has been a high degree of informatization during the period 1993-1996. In 1995, for example, 31 percent of the national government units had no use of electronic archives, management systems or mail systems, while in 1996, only 4 percent had no use of these applications. Similarly, in 1995, 6 percent of the municipalities used electronic incoming mail and electronic case handling, while in 1996, 51 percent of the municipalities used these applications.

When considering the variety of tasks in which EDI is used, approximately 50 percent of the counties used it to obtain information about products and services, whereas roughly 42 percent use it for payment. By contrast, only $5 \%$ of the municipalities used it for payment purposes. Thus counties appear to have a significant lead in utilising electronic commerce. This most likely attributable to the business-to-business EDI predominant in the health sector, which is primarily administrated by the counties in Denmark. 
Table 5. IT in the public sector, 1995-1996. (percentages)

\begin{tabular}{llllll}
\hline $\begin{array}{l}\text { Level of } \\
\text { governme } \\
\text { nt/ year }\end{array}$ & $\begin{array}{l}\text { No use of } \\
\text { electronic } \\
\text { archives, } \\
\text { management } \\
\text { or mail } \\
\text { systems }\end{array}$ & $\begin{array}{l}\text { Electronic } \\
\text { mail used for } \\
\text { internal or } \\
\text { external use }\end{array}$ & $\begin{array}{l}\text { Electronic } \\
\text { archiving or } \\
\text { electronic case } \\
\text { handling } \\
\text { systems } \\
\text { introduced }\end{array}$ & $\begin{array}{l}\text { Electronic } \\
\text { handling of } \\
\text { incoming mail } \\
\text { and electronic } \\
\text { case handling }\end{array}$ \\
\hline National & 1993 & 31 & 49 & 20 & 0 \\
& $1995 \mathrm{a}$ & 15 & 34 & 49 & 2 \\
& $1996 \mathrm{a}$ & 4 & 14 & 46 & 35 \\
Municipali & $1995 \mathrm{~b}$ & 11 & 45 & 38 & 6 \\
ties & $1996 \mathrm{c}$ & 2 & 19 & 28 & 51 \\
Counties & $1995 \mathrm{~b}$ & 7 & 36 & 57 & 0 \\
& $1996 \mathrm{c}$ & 0 & 21 & 14 & 64 \\
\hline
\end{tabular}

Note. $a=$ spring, $b=$ primo, $c=$ ultimo

Source. Danish Ministry of Research and Information Technology (1997).

Table 6. Electronic commerce: The content (percentages)22

\begin{tabular}{lccccc}
\hline $\begin{array}{l}\text { Level of } \\
\text { gov'ment }\end{array}$ & $\begin{array}{c}\text { Informa- } \\
\text { tion on } \\
\text { products/ } \\
\text { services }\end{array}$ & $\begin{array}{c}\text { Prices and } \\
\text { discounts }\end{array}$ & $\begin{array}{c}\text { Delivery } \\
\text { conditions }\end{array}$ & $\begin{array}{c}\text { Ordering of } \\
\text { products/ } \\
\text { services }\end{array}$ & $\begin{array}{c}\text { Payment for } \\
\text { products/ } \\
\text { services }\end{array}$ \\
\hline Munici- & 6 & 4 & 3 & 5 & 6 \\
palities & 50 & 34 & 25 & 34 & 42 \\
Counties & 50 & 7 & 5 & 6 & 2 \\
Enterprises & 15 & & & & \\
\hline
\end{tabular}

In the private sector we find that the choices faced by managers in the public and private sector on business integration issues are ambiguous and characterised by substantial uncertainty on for example the role of intermediates, direct sale, hyper-shift in business partners and the pull/push of global enterprises at the local markets.

At the private market, the role of intermediaries is changing but seems not to eliminate either the intermediaries or the retail stores. We do see showrooms popping up and market share taken by virtual intermediaries such as Amazon and in Scandinavia Boxman for CD shopping. The entertainment industry and software are in Denmark among the economically favoured by the Internet. The public sector is confronted with this development not only from a regulation point of view, but also in daily operations in for example procurement function.

\section{CONCLUSIONS}

The drive towards electronic commerce organisation is a troublesome path for government, enterprises and consumers worldwide. The Danish government is stimulating the use of electronic commerce using direct and indirect policy initiatives on central, governmental regulation and establishment of greens enabling selfregulation. Also, the governments own, organisational management is in Denmark seen as a mean to exalt electronic commerce.

Onwards, the fist on proprietory standards and the UN/EDIFACT is an ongoing source of delaying, stimulating or preventing electronic commerce depending on the business sector and the size of market actor addressed. In Denmark, the direct access and value added network supporters have so far been the dominating mean to

22205 of the 275 Danish municipalities and 12 of the 14 Danish counties participated in the survey Source. Danish Ministry of Information Technology and Research (1997). 
transport electronic documents in business transactions. The Internet and XML technology is at the turn of the century challenging the way of doing business within this field. Some view this as the big blue to speed the diffusion of electronic commerce; others are worried that the incentive to investment and pull the partners in the value chain to use EDI might be lost. Finally, our study concludes that the debate on business integration issues is ambiguous and characterised by substantial uncertainty on, for example, the role of intermediates, direct sale, hyper-shift in business partners and the pull/push of global enterprises at the local markets.

The future areas of research to be undertaken within this field includes development on the technical elements, the institutional and organisational features, the suppliers and the demand pull patterns. On the technical elements the battle between EDIFACTand ANSI X.12 versus proprietory will be supplemented with technical issues on transportationmedia and dataintegration issues. The transportation media include the dilemma on direct access, VANS-operated EDI-transport and Internettechnology. The heavily consumer orientation in the current design of Internet application enabling the marketing, sale and service of either digital or physical products are in our view holding the potential to define businesses and challenge the role of intermediaries.

In turn, the choices faced by managers in the public and private sector on business integration issues is ambiguous and characterised by substantial uncertainty on for example the role of intermediates, direct sale, hyper-shift in business partners and the pull/push of global enterprises at the local markets. Also, there is a major need for studies on methodological issues such as the definition of use and the business impacts of the use. At the Danish Center for Electronic Commerce (CEC) at the Center for Research on IT in the Public Sector (CIPS) these issues are addressed in our ongoing research on IT.

\section{REFERENCES}

Andersen, K. V. (1998). Health data networking: capability, interaction, orientation, and political values. Hawaii International Conference on Systems Sciences (HICCS).

Andersen, K. V. (Ed.). (1997). EDI and data networking in the public sector: Governmental action, diffusion, and impacts. Amsterdam: Kluwer.

Andersen, K. V., Bjørn-Andersen, N., \& Juul, N. C. (1998). Elektronisk handel og dokumentudveksling: EDI-anvendelsen i Danmark. Copenhagen: Samfundslitteratur.

Choi, Soon-Yong, Stahl, Dale O., \& Whinston, Andrew (1997). The economics of electronic commerce. Indianapolis, IN: MacMillan.

Damsgaard, J.,\& Lyytinen, K. (1997). Government Intervention in the Diffusion of EDI: Goals and Conflict. In K. V. Andersen, K. V. (Ed.), EDI and Data Networking in the Public Sector: Governmental Action, Diffusion, and Impacts. Amsterdam: Kluwer.

Danish Ministry of Information Technology and Research. (1996). Information technology in Danish government. Copenhagen: Author.

Danish Ministry of Information Technology and Research. (1997). Authorities Heading for a Fall: IT Policy White Paper Presented to the Folketing 1997

Danish Ministry of Research and Information Technology (1998). Information technology in Denmark. Copenhagen: Author.

Fuen County. (1995). FYNCOM: Det fynske sundhedsdatanet [The health data network in Fuen]. Odense: Danish Center for Health Informatics.

Fuen County. (1996). MEDCOM: Det danske sundhedsdatanet [MEDCOM: The Danish health data network]. Odense: Danish Center for Health Informatics.

Graham, I., \& Lobet-Maris, C. (1994). EDI impact: Social and economic impact of electronic data interchange. TEDIS Project C9. Brussels: European Commission.

Saxena, K. B. C., \& Wagenaar, R. W. (1997). Critical success factors of EDI technology transfer: A conceptual framework. Proceedings of the $3^{\text {rd }}$ European Conference on Information Systems (ECIS) (pp. 57-74). June. Athens, Greece.

Scala, S., \& MacGrath, R., Jr. (1993). Advantages and disadvantages of electronic data interchange. Information \& Management, 25(2), 85-91.

Statistics Denmark (1998). Danmark i tal. Copenhagen: Statistics Denmark. 